a Universidade Estadual do Norte Fluminense Darcy Ribeiro, Programa de Pós-Graduação em Ciências Naturais, Laboratório de Ciências Químicas, Avenida Alberto Lamego 2000, CEP 28013-602, Campos dos Goytacazes-RJ, Brasil.

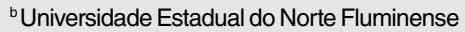
Darcy Ribeiro, Laboratório de Biologia do Reconhecer, Avenida Alberto Lamego 2000, CEP 28013-602, Campos dos GoytacazesRJ, Brasil.

c Universidade Federal do Rio de Janeiro, Laboratório de Produtos Bioativos, CEP 27930-560 Macaé-RJ, Brasil.

a Departamento de Química, Instituto de Química, Universidade Federal Rural do Rio de Janeiro, CEP 20000-000, Seropédica-RJ, Brasil;

`E-mail: curcino@uenf.br

Recebido: 23 de Março de 2021

Aceito: 23 de Março de 2021

Publicado online: 17 de Junho de 2021

\section{Anti-Mycobacterium tuberculosis Activity of Compounds from Cedrela fissilis Vell. Seeds (Meliaceae)}

\author{
Atividade anti-Mycobacterium tuberculosis de compostos das sementes de \\ Cedrela fissilis Vell. (Meliaceae)
}

Thalya S. R. Nogueira, a Michel de S. Passos, ${ }^{a}$ Sanderson D. Calixto, ${ }^{b}$ Thatiana L. B. Ventura, ${ }^{b}$ Elena Lassounskaia, ${ }^{b}$ Michelle F. Muzitano, ${ }^{b, c}$ Raimundo Braz-Filho, a,d Ivo J. C. Vieira, ${ }^{a}$ (D)

The phytochemistry of the species Cedrela fissilis Vell., family Meliaceae, also popularly known as "cedro rosa", was investigated, leading to the isolation of four compounds from the crude methanolic extract of its seeds; the triterpene Piscidinol A (1), and three limonoids, Andirolide N (2), Mexicanolide (3), and Proceranolide (4). Subsequently, the antimycobacterial, anti-inflammatory, and cytotoxicity activities of these compounds were investigated. The Proceranolide limonoid (4) presented the best result for the investigated biological activities, with moderate antimycobacterial activity, considerable inhibition of nitric oxide production, and low cytotoxicity. The Andirolide N (2) and Proceranolide (4) limonoids are being reported for the first time in the Cedrela genus.

Keywords: Cedrela fissilis; Meliaceae; limonoids; biological activities

\section{Introduction}

Tuberculosis (TB) is a bacterial infectious disease ${ }^{1}$, neglected, with high mortality rates in the world. ${ }^{2}$ Transmission occurs via the respiratory tract, which primarily affects the lungs. However, other organs can be affected. ${ }^{3}$ TB infection may be present in latent or active forms, whereby in the first there are no symptoms and in the second, symptoms include fever, dry or productive cough, sore throat, sweating, weight loss, and tiredness or weakness. ${ }^{3}$

According to the WHO, 484,000 people developed resistance to rifampicin in 2019, which is the most active medicine against tuberculosis bacillus, with $78 \%$ of these being multiresistant. ${ }^{2}$ Therefore, there is a necessity to develop new forms of diagnosis and treatment.

Brazil stands out in terms of strategies to contain tuberculosis, having achieved an $8 \%$ reduction in the number of deaths from tuberculosis in the last decade. ${ }^{4}$ In addition, new forms of treatment and diagnosis were incorporated into the Single Health System (SUS) in $2020 .^{5}$ It is worth mentioning that the SUS offers, free of charge, diagnosis, treatment, and follow-up by specialized professionals. ${ }^{7}$ Nonetheless, actions to contain the incidence of cases, especially among the population deprived of liberty (PDL), need to be intensified. The Report of Tuberculosis in Brazil outlined 73,864 cases in 2019, of which 11.1\% were among PDL, surpassing the cases of co-infection with HIV. ${ }^{8}$

Research into secondary metabolites of Meliaceae species and their biological activities have increased, as these plants present activities such as insecticidal, antiviral, anthelmintic, anti-rheumatic, anti-cancer, and anti-inflammatory, which are usually related to modified triterpenes, denominated limonoids. ${ }^{9}$ These activities have also been described for the Cedrela species. ${ }^{9}$ The Cedrela genus contains 18 species $^{10,11}$ and the majority of the chemical compounds described in the literature for this species are terpenoids. In addition, $54.6 \%$ of the triterpenoids found are limonoids. ${ }^{12}$

The current study aimed to isolate secondary metabolites from crude methanolic extract of Cedrela fissilis seeds and evaluate their antimycobacterial, anti-inflammatory, and cytotoxic activities

\section{Results and Discussion}

The triterpene, Piscidinol A (1) $)^{13}$, and three limonoids, Andirolide N (2) ${ }^{14}$, Mexicanolide $(3)^{15}$, and Proceranolide $(4)^{16}$ (Figure 1), were isolated from the methanolic extract of $C$. 
fissilis seeds, characterized by their spectral data of ${ }^{1} \mathrm{H}$ and ${ }^{13} \mathrm{C}-\mathrm{NMR}$ (1D and 2D) and high resolution spectrometry (HRESIMS), and compared with data described in the literature (supplementary material).

These limonoids (2-4) were classified as mexicanolide type, and are reported as the main type of limonoid of the genus Cedrela. ${ }^{12}$ In the comparison of their structures (Figure 1), the main differences observed are restricted to the carbon atom C-3 $\left(\mathrm{sp}^{3}\right.$ oxygenated, $\mathbf{2}$ and $\mathbf{4}$, or carbonyl sp ${ }^{2}$, $\mathbf{3})$ and the double bond positions $\left(\Delta^{8-14}, \mathbf{3}\right.$ and $\mathbf{4}$, or $\left.\mathrm{D}^{14-15}, \mathbf{2}\right)$.

The antimycobaterial, anti-inflammatory, and cytotoxicity activities of these compounds were investigated and the corresponding minimum inhibitory concentration $50 \%\left(\mathrm{MIC}_{50}\right)$, shown in Table 1.

All compounds were active with antimycobacterial activity against both strains of $M$. tuberculosis. However, compared to rifampicin $\mathrm{MIC}_{50}$ values, proceranolide (4) showed moderate inhibitory effects, with $\mathrm{MIC}_{50}$ values for
$\mathrm{H} 37 \mathrm{Rv}$ and M299 of $37.6 \pm 0.4 \mu \mathrm{g} / \mathrm{mL}$, and $44.9 \pm 1.0 \mu \mathrm{g} / \mathrm{mL}$, respectively, while mexicanolide (3) showed weak inhibitory effects $\left(\mathrm{MIC}_{50-\mathrm{H} 37 \mathrm{Rv}}=\geq 500 \mu \mathrm{g} / \mathrm{mL} ; \mathrm{MIC}_{50-\mathrm{M} 299}=347.7 \pm 1.0\right.$ $\mu \mathrm{g} / \mathrm{mL}$ ). The effects of these compounds on the growth of both strains of M. tuberculosis are shown in Figure 2.

In the case of inhibition of nitric oxide (NO) production, all compounds showed some activity. However, limonoid $4(26.9 \pm 0.6 \mu \mathrm{g} / \mathrm{mL})$ demonstrated considerable inhibition when its $\mathrm{IC}_{50}$ values were compared to the positive control (L-NMMA - $13.2 \pm 0.6 \mu \mathrm{g} / \mathrm{mL}$ ) (Table 1). The effects of each of the compounds on the inhibition of NO production are reported in Figure 3A.

These compounds were also evaluated for their cytotoxicity, which was observed in all compounds tested (Table 1). However, 4 showed higher $\mathrm{IC}_{50}$ values than the others. Figure 3B presents the cytotoxicity effects.

Boeno et al. ${ }^{17}$ carried out a biological assay with similar methodology and evaluated the anti-mycobacterial<smiles>C[C@H](C[C@H](O)[C@@H](O)C(C)(C)O)[C@H]1CC[C@]2(C)C3=CC[C@H]4C(C)(C)C(=O)CC[C@]4(C)[C@H]3CC[C@H]12</smiles>

1

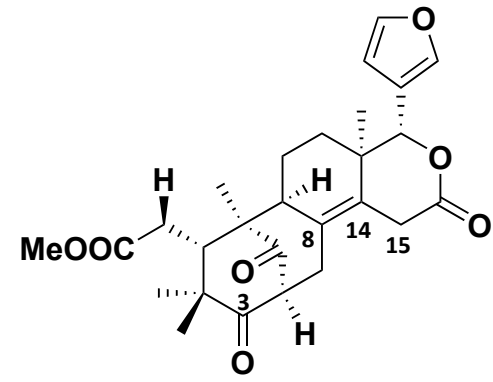

3

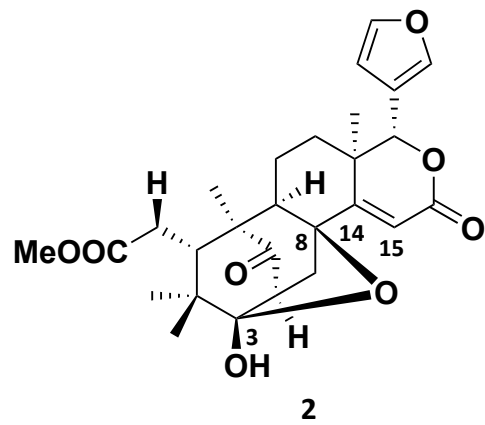

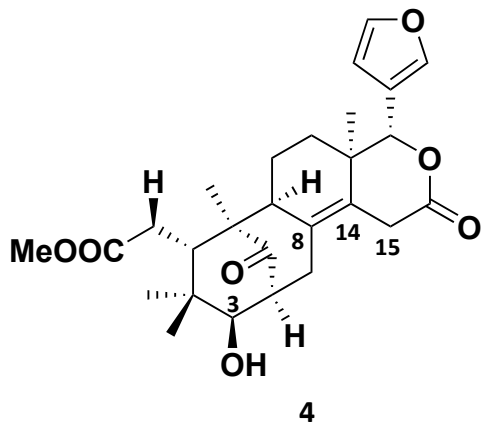

Figure 1. Compounds isolated from C. fissilis seeds

Table 1. Inhibitory effects of the compounds isolated from C. fissilis seeds on growth of M. tuberculosis H37Rv and M299 strains in culture, NO production by LPS-stimulated RAW 264.7 macrophages, and assessment of cytotoxicity

\begin{tabular}{lcccc}
\hline \multirow{2}{*}{ Compounds } & \multicolumn{2}{c}{ MIC $_{\mathbf{5 0}}(\boldsymbol{\mu g} / \mathbf{m L})$} & \multicolumn{2}{c}{$\mathbf{I C}_{\mathbf{5 0}}(\boldsymbol{\mu g} / \mathbf{m L})$} \\
\cline { 2 - 5 } & $\mathbf{H 3 7 R v}$ & $\mathbf{M 2 9 9}$ & NO & MTT \\
\hline 1 & $49.6 \pm 0.5$ & $66.0 \pm 1.0$ & $36.2 \pm 0.7$ & $47.4 \pm 0.2$ \\
2 & $60.1 \pm 0.3$ & $50.4 \pm 1.0$ & $43.9 \pm 0.9$ & $225.9 \pm 0.2$ \\
3 & $\geq 500$ & $347.7 \pm 1.0$ & $30.6 \pm 0.7$ & $\geq 500$ \\
4 & $37.6 \pm 0.4$ & $44.9 \pm 1.0$ & $26.9 \pm 0.6$ & $321.3 \pm 0.1$ \\
Rifampicin $^{1}$ & $0.8 \pm 0.1$ & $0.9 \pm 0.2$ & $\mathrm{XX}$ & $\mathrm{XX}$ \\
L-NMMA $^{2}$ & $\mathrm{XX}$ & $\mathrm{XX}$ & $13.2 \pm 0.6$ & $\mathrm{XX}$ \\
\hline
\end{tabular}

${ }^{1}$ Standard antimycobacterial drug; ${ }^{2}$ Standard nitric oxide inhibitor; Mean value $\pm \mathrm{SD} ; \mathrm{XX}$ - not defined 


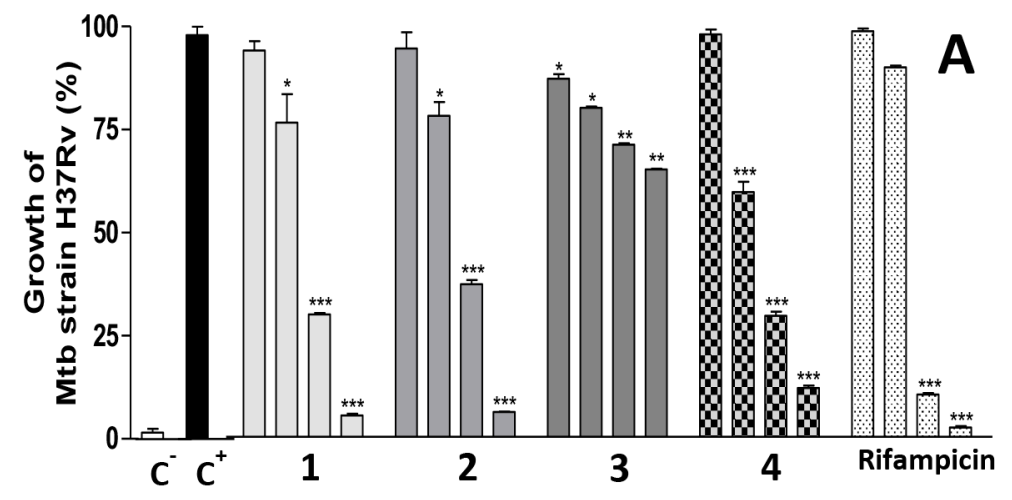

B

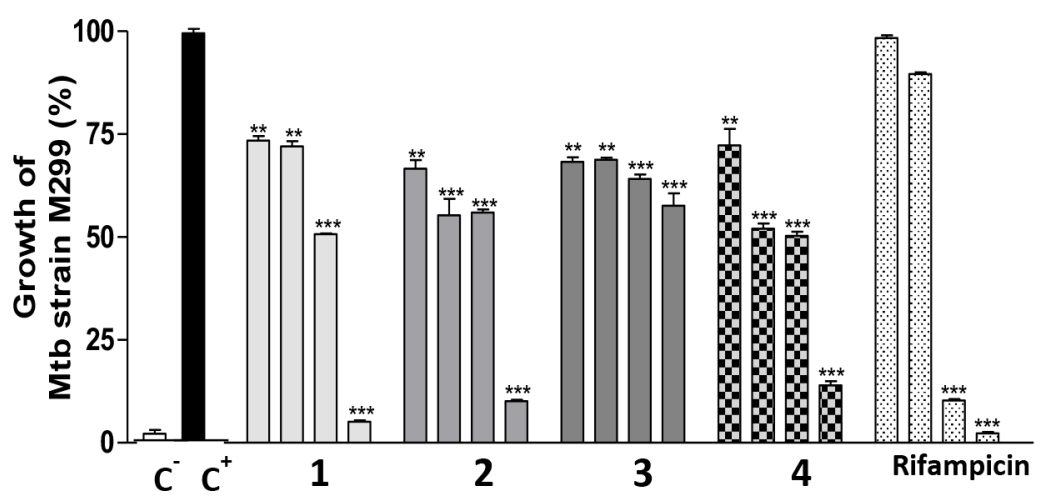

Figure 2. Effects of the compounds from C. fissilis on M. tuberculosis growth in bacterial culture. Bacterial suspensions $\left(1 \times 10^{6} \mathrm{CFU} / \mathrm{well}\right)$ of M. tuberculosis strain H37Rv (A) and clinical isolate M299 (B) were treated or untreated with samples $(4,20,100$ and $500 \mu \mathrm{g} / \mathrm{mL})$ or rifampicin $(0.00032,0.0016,0.008,1$ $\mu \mathrm{g} / \mathrm{mL}$ for the strain H37Rv and 0.008, 0.04, 0.2 and $10 \mu \mathrm{g} / \mathrm{mL}$ for the strain M299) for 5 days. Bacterial growth in the resulted cultures was quantified by MTT test. Data are presented as a percentage of bacterial growth of each treated culture compared to the growth of corresponding untreated culture (100\%). The four bars for each compound refer to concentrations tested in ascending order. Bacterial suspensions treated with antibiotic rifampicin and culture medium 7H9 supplemented with ADC (C-) were used as a negative control. Untreated bacterial suspension served as a positive control (C+). The results presented are mean values obtained over three experiments, each done in triplicate. $* * * p<0.001, * * \mathrm{p}<0.01$ and $* \mathrm{p}<0.05$ compared to untreated group

activity and cytotoxicity of triterpenes, and another class of compounds isolated from Homalolepis suffruticosa Engl. (Simaroubaceae).

The results for Piscidinol A (1) were consistent with those presented by Boeno et al. ${ }^{17}$ for Hispidol A, Nilocitine, and $\alpha$-dihydronylocytine; all of these triterpenes are tirulan type. Thus, it can be deduced that the $\mathrm{OH}$ group at $\mathrm{C}-3$ contributes to inhibition potential of Mycobacterium growth, for both strains of M. tuberculosis. Hispidol showed better MIC values than Piscidinol (1), and similar to the rifampicin $\mathrm{MIC}_{50}$. On the other hand, all of these triterpenes were cytotoxic.

With respect to the limonoids, Passos et al. ${ }^{18}$, using a similar methodology to that described in the current paper, tested the anti-tuberculosis, anti-inflammatory, and cytotoxic activities of the limonoids Morenolide, Nimbinene, Nimbinal, Nimbandiol, and Salannin, and also compounds of other classes, which were isolated of Azadirachta indica roots. These limonoids are classified as $\mathrm{C}-\mathrm{seco}$, and are more active and cytotoxic than limonoids 2-4, which are B,D-seco.
It is suggested that the structural abundance of limonoids should be studied, and possible structural modifications carried out to verify the possibility of more active or less cytotoxic compounds.

\section{Material and Methods}

\subsection{General experimental procedures}

Column Chromatography (CC) was performed on silica gel 60 (0.063-0.200 mm, Merck). Preparative Thin Layer Chromatography (PTLC) was performed on silica gel 60 $\mathrm{PF}_{254}$ containing gypsum (Merck). Methanol $\left(\mathrm{CH}_{3} \mathrm{OH}-\right.$ 99.8\%), dichloromethane $\left(\mathrm{CH}_{2} \mathrm{Cl}_{2}-99.5 \%\right), n$-hexane $(98.5 \%)$, acetone $(99.5 \%)$, and ethyl acetate (EtOAc 99.5\%) were used as mobile phase solvents, purchased from Synth (São Paulo, Brazil). 1D and 2D NMR experiments were performed using a $500 \mathrm{MHz}$ Bruker Ascend 500 NMR spectrometer, operating at $500 \mathrm{MHz}$ for ${ }^{1} \mathrm{H}$ NMR and $125 \mathrm{MHz}$ for ${ }^{13} \mathrm{C}$ NMR. Deuterated solvents, chloroform 

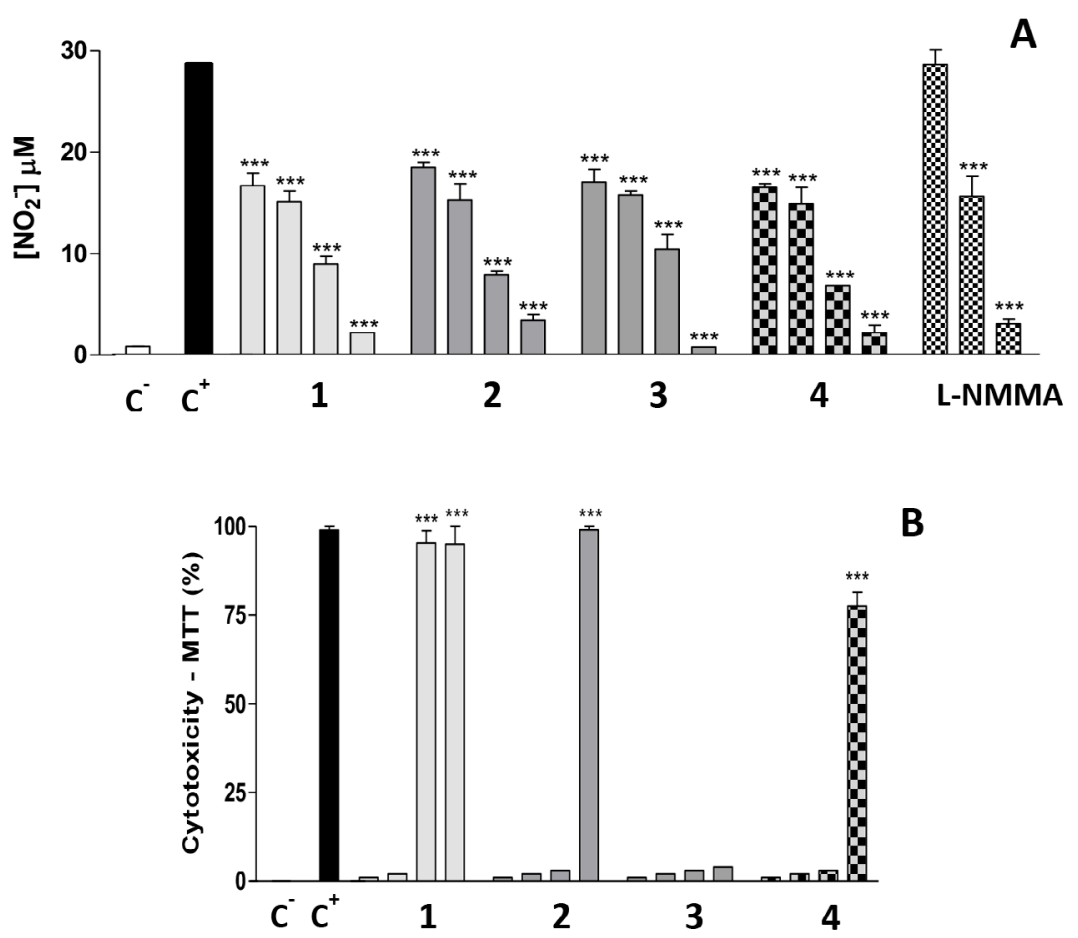

Figure 3. Inhibitory effect of the compounds on NO production in macrophages RAW 264.7 stimulated by LPS (A) and cell citotoxicity evaluation by MTT assay (B). Plated RAW 264.7 macrophages $\left(5 \times 10^{5}\right.$ cells / mL) were stimulated by LPS $(1 \mu \mathrm{g} / \mathrm{mL})$ and treated with the recommendations of 4,20 , 100 and $500 \mu \mathrm{g} / \mathrm{mL}$ for $24 \mathrm{~h}$. Evaluation of NO production took place using the Griess method. As negative control of NO production (C-), culture of unstimulated and untreated macrophages was used and as positive control $(\mathrm{C}+)$, culture of macrophages only stimulated by LPS. L-NMMA was used at the concentrations 4,20 and $100 \mu \mathrm{g} / \mathrm{mL}(\mathrm{A})$. In the toxicity tests, after $24 \mathrm{~h}$ of the stimulated and treated cell culture, 10 $\mu \mathrm{L}$ of the MTT solution / well was added and the formazan crystals solubilized in acidified isopropanol. As a negative control (C-) of cell death, a culture of macrophages only stimulated by LPS was used and as a positive control $(\mathrm{C}+)$, a culture of macrophages treated with $1 \%$ Triton $\mathrm{X}-100(\mathrm{~B})$. Values were represented as mean \pm standard deviation and different groups considered significant according to $\mathrm{p}<0.05(*), \mathrm{p}<0.01(* *)$ and $\mathrm{p}<0.001(* * *)$

$\left(\mathrm{CDCl}_{3}\right)$, methanol $\left(\mathrm{CD}_{3} \mathrm{OD}\right)$, and pyridine (pyridine- $\left.d_{5}\right)$, containing TMS (tetramethylsilane) as an internal standard, were used. HR-ESI-MS were obtained on a micrOTOF-Q II Bruker Daltonics mass spectrometer, with the use of the positive ion mode of analysis.

\subsection{Plant material}

Cedrela fissilis (SisGen code AC8E4F3) seeds were collected in July 2018 at Campos dos Goytacazes, RJ, Brazil (latitude $21^{\circ} 41^{\prime} 56.9^{\prime \prime} \mathrm{S}$, longitude $41^{\circ} 12^{\prime} 22.0^{\prime \prime} \mathrm{W}$ ). The voucher specimen (H11234) was deposited in the herbarium of the Universidade Estadual do Norte Fluminense Darcy Ribeiro (UENF).

\subsection{Extraction and isolation}

Cedrela fissilis seeds were dried and powdered. The extraction was performed with methanol (CFM, $49.4 \mathrm{~g}$ ). Part of the methanolic extract $(24.3 \mathrm{~g}$ ) was fractionated by silica gel $\mathrm{CC}$, with a polar gradient of $\mathrm{CH}_{2} \mathrm{Cl}_{2}: \mathrm{MeOH}$, obtaining 8 fractions (CFM1 - CFM9). Mexicanolide (3- 138.9 $\mathrm{mg}$ ) was isolated as precipitate of fraction CFM5. CFM6 was chromatographed, with a polar gradient of $n$-hexane: acetone, generating 11 fractions (CM6.1 - CM6.11). Fraction CFM6.7 (764.2 mg) was chromatographed, with a polar gradient of $n$-hexane: EtOAc, obtaining 11 fractions (CFM6.7.1 - CFM6.7.11). Proceranolide (4) was identified in fraction CFM6.7.8 (286.9 mg). Fraction CFM6.7.7 was chromatographed, with a polar gradient of $n$-hexane: EtOAc, obtaining 4 fractions (CFM6.7.7.1 - CFM6.7.7.4). PTLC was performed with fraction CFM6.7.7.1 (44.4 mg), with $2 \%$ of $\mathrm{CH}_{2} \mathrm{Cl}_{2}: \mathrm{MeOH}$, obtaining piscidinol A (1-11.7 mg) and andirolide $\mathrm{N}(\mathbf{2}-10.5 \mathrm{mg})$ of fractions CFM6.7.7.1.A and CFM6.7.7.1.B, respectively.

\subsection{Antimycobacterial activity assay}

Two Mycobacterium tuberculosis strains (low virulent laboratory strain H37Rv, ATCC 27294, and highly virulent Mycobacterium tuberculosis Beijing strain M299 isolated from TB patient in Mozambique) were evaluated for virulence in previous study. ${ }^{19}$ Mycobacterial strains were grown in suspension in 7H9 Middlebrook medium, containing $10 \%$ albumin dextrose complex (ADC), $0.5 \%$ glycerol and $0.05 \%$ Tween- 80 at $37{ }^{\circ} \mathrm{C}$, under Biosecurity level 3 containment conditions. The bacterial suspensions were plated $(1 \times 106 \mathrm{CFU} /$ well in 96-well plate $)$ and incubated in the presence of compounds at concentrations of $(4,20,100$, and $500 \mu \mathrm{g} / \mathrm{mL}$ ) or rifampicin (ranging from 0.00032 to $1 \mu \mathrm{g} / \mathrm{mL}$ for $M$. tuberculosis $\mathrm{H} 37 \mathrm{Rv}$ strain and from 0.008 to $10 \mu \mathrm{g} / \mathrm{mL}$ for clinical M. tuberculosis 
isolate M299). The MTT (3-[4, 5-dimethylthiazol-2-yl]-2, 5 diphenyl tetrazolium bromide) assay was performed to evaluate the bacterial growth ${ }^{20}$, using the procedures described by Ventura et al. ${ }^{21}$

Both strains of Mycobacteria were incubated with Middlebrook 7H9 medium supplemented with $0.05 \%$ glycerol, $0.05 \%$ Tween 80, and ADC (albumin dextrose catalase). Cells were plated at a density of $1 \times 106 \mathrm{CFU} /$ well in a 96-well plate and treated with the samples. The plate was incubated at $37^{\circ} \mathrm{C}$ and $5 \% \mathrm{CO}_{2}$ for 5 days. Subsequently, the MTT solution was incubated for $3 \mathrm{~h}$, and the lysis buffer was added [20\% w/v sodium dodecyl sulphate (SDS) and 50\% dimethylformamide (DMF) in distilled water, $\mathrm{pH}$ 4.7]. The plate was incubated overnight, and the reading was carried out using a spectrophotometer at $570 \mathrm{~nm}$. As a positive control was used untreated M. tuberculosis and negative control was used Middlebrook 7H9 medium.

\subsection{Anti-inflammatory activity assay}

Macrophages RAW 264.7 were obtained from the American Type Culture Collection (ATCC) and grown at $37{ }^{\circ} \mathrm{C}$ and $5 \% \mathrm{CO}_{2}$ in DMEM F-12 supplemented with $10 \% \mathrm{FCS}$ and gentamicin $(50 \mu \mathrm{g} / \mathrm{mL})$. Posteriorly, they were seeded in 96-well tissue culture plates in the presence or absence of four concentrations of the samples $(4,20,100$, and $500 \mu \mathrm{g} / \mathrm{mL}$ ) and/or LPS (Escherichia coli 055:B5; Sigma-Aldrich) for 24h of incubation. Afterward, supernatants were collected, and the concentration of nitric oxide was determined by the Griess Method..$^{22}$ As a positive control, NG-methyl-L-arginine acetate salt (L-NMMA, Sigma-Aldrich, $98 \%$ purity) was used at concentrations of 4, 20 and $100 \mu \mathrm{g} / \mathrm{mL}$.

\subsection{Cytotoxicity assay}

Cytotoxicity was evaluated with the MTT assay, checking the mitochondrial-respiration-dependent reduction. ${ }^{23}$ Macrophages RAW264.7 $(5 \times 105$ cells $/ \mathrm{mL})$ were incubated at $37^{\circ} \mathrm{C}$ in $5 \% \mathrm{CO}_{2}$ for $24 \mathrm{~h}$ in 96 -well plates with increasing doses of the test compound $(4.0,20,100$, and $500 \mu \mathrm{g} / \mathrm{mL})$. Posteriorly, $5 \mu \mathrm{L}$ of MTT solution $(5 \mathrm{mg} / \mathrm{mL})$ were added to each well. After incubation for $2 \mathrm{~h}$ at $37^{\circ} \mathrm{C}$, the formazan crystals in viable cells were solubilized in $\mathrm{HCl}(4 \mathrm{mM})$ and added to isopropanol. The absorbance of each well was then read at $570 \mathrm{~nm}$. Non-treated cells were used as a positive control and $1 \%$ Triton X-100 detergent-treated cells as a negative control.

\subsection{Statistical analysis}

Results were tabulated by LabChart 7 and statistically analyzed using GraphPad Prisma 4. The tests were performed in triplicate and the values are expressed as mean $\pm \mathrm{SD}$.

\section{Conclusions}

Four compounds were isolated from the seeds of Cedrela fissilis, namely: Piscidinol A (1), Andirolide N (2), Mexicanolide (3), and Proceranolide (4). Compunds 2 and 4 are being reported for the first time in Cedrela genus. Moreover, compound $\mathbf{4}$ presented moderate antimycobacterial activity and a considerable inhibitory effect on NO production and low cytotoxicity.

\section{Acknowledgments}

The authors are grateful to the Fundação de Amparo à Pesquisa do Estado do Rio de Janeiro (FAPERJ), Conselho Nacional de Desenvolvimento Científico e Tecnológico (CNPq), and Coordenação de Aperfeiçoamento de Pessoal de Nível Superior (CAPES)—Finance Code 001.

\section{References}

1. Sasindran, S. J.; Torrelles, J. B.; Mycobacterium Tuberculosis Infection and Inflammation: what is Beneficial for the Host and for the Bacterium? Frontiers in Microbiology 2011, 2, 1. [CrossRef]

2. World Health Organization.; Available in: $<$ https://www.who. int/publications/i/item/9789240013131>. Acessed in: 7 January 2021.

3. Pereira, S. M.; Dantas, O. M. S.; Ximenes, R.; Barreto, M. L.; Vacina BCG contra tuberculose: efeito protetor e políticas de vacinação. Revista de Saúde Pública 2007, 41, 59. [CrossRef]

4. Ministério da Saúde.; Available in: <https://www.gov.br/saude/ pt-br/assuntos/noticias/brasil-reduz-em-8-o-numero-de-mortespor-tuberculose-na-ultima-decada>. Acessed in: 7 January 2021.

5. Ministério da Saúde.; Available in: <https://www.gov.br/saude/ pt-br/assuntos/noticias/ministerio-da-saude-amplia-tratamentoe-diagnostico-da-tuberculose-no-sus $>$. Acessed in: 7 January 2021.

6. Ministério da Saúde.; Available in: <https://www.gov.br/saude/ pt-br/centrais-de-conteudo/boletim-tuberculose-2020-marcas-1pdf $>$. Acessed in: 7 January 2021.

7. Ministério da Saúde.; Available in: <http://www.aids.gov.br/ pt-br/pub/2019/manual-de-recomendacoes-para-o-controle-datuberculose-no-brasil>. Acessed in: 7 January 2021.

8. Ministério da Saúde.; Available in: <https://www.gov.br/saude/ pt-br/centrais-de-conteudo/boletim-tuberculose-2020-marcas-1pdf>. Acessed in: 7 January 2021.

9. Tan, Q.; Luo, X.; Meliaceous Limonoids: Chemistry and Biological Activities. Chemical Reviews 2011, 111, 7437. [CrossRef]

10. The Plant List.; Available in: $<$ http://www.theplantlist.org/tpl1.1/ search?q=cedrela $>$. Acessed in: 7 January 2021. 
11. Palacios, W. A.; Santiana, J.; Iglesias, J.; A new species of Cedrela (Meliaceae) from the eastern flanks of Ecuador. Phytotaxa 2019, 393, 84. [CrossRef]

12. Nogueira, T. S. R.; Passos, M. S.; Nascimento, L. P. S.; Boeno, S. I. S.; de Carvalho Junior, A.; Azevedo, O. A.; Terra, W. S.; Vieira, M. G. C.; Braz-Filho, R.; Curcino Vieira, I. J.; Chemical Compounds and Biologic Activities: A Review of Cedrela Genus Molecules 2020, 25, 540. [CrossRef]

13. Ribeiro, S. C. M.; Gomes, L. L.; Amaral, E. P.; Andrade, M. R. M.; Almeida, M. A.; Rezende, A. L.; Lanes, V. R.; Carvalho, E. C. Q.; Suffys, P. N.; Mokrousov, I.; Lasunskaia, E. B.; Mycobacterium tuberculosis strains of the modern sublineage of the Beijing family are more likely to display increased virulence than strains of the ancient sublineage. Journal of Clinical Microbiology 2014, 52, 2615. [CrossRef]

14. Moodley, S., Koorbanally, N. A., Moodley, T., Ramjugernath, D., Pillay, M.; The 3-(4,5-dimethylthiazol-2-yl)-2,5-diphenyl tetrazolium bromide (MTT) assay is a rapid, cheap, screening test for the in vitro anti-tuberculous activity of chalcones. Journal of Microbiological Methods 2014, 104, 72. [CrossRef]

15. Ventura, T. L. B.; Calixto, S. D., Abrahim-Vieira, B. d. A.; de Souza, A. M. T.; Mello, M. V. P.; Rodrigues, C. R.; de Mariz e Miranda, L. S.; de Souza, R. O. M.; Leal, I. C. R.; Lasunskaia, E.; Muzitano, M. F.; Antimycobacterial and anti-inflammatory activities of substituted chalcones focusing on an anti-tuberculosis dual treatment approach. Molecules 2015, 20, 8072. [CrossRef]

16. Park, P.-H.; Kim, H.S.; Jin, X.Y.; Jin, F.; Hur, J.; Ko, G.; Sohn, D. H.; KB-34, a newly synthesized chalcone derivative, inhibits lipopolysaccharide-stimulated nitric oxide production in RAW 264.7 macrophages via heme oxygenase-1 induction and blockade of activator protein-1. European Journal of Pharmacology 2009, 606, 215. [CrossRef]
17. Muzitano, M. F.; Cruz, E. A.; de Almeida, A. P.; da Silva, S. A.; Kaiser, C. R.; Guette, C.; Bergmann, B. R.; Costa, S. S.; Quercitrin: An Antileishmanial Flavonoid Glycoside from Kalanchoe pinnata. Planta Medica 2006, 72, 81. [CrossRef]

18. McChesney, J.; D.; Dou, J.; Sindelar, R. D.; Goins, D. K.; Walker, L. A.; Rogers, R. D.; Tirucallane-type triterpenoids: NMR and X-ray diffraction analyses of 24-epi-piscidinol A and piscidinol A. Journal of Chemical Crystallography 1997, 27, 283. [CrossRef]

19. Tanaka, Y.; Sakamoto, A.; Inoue, T.; Yamada, T.; Kikuchi, T.; Kajimoto, T.; Muraoka, O.; Sato, A.; Wataya, Y.; Kim, H.S.; Tanaka, R.; Andirolides H-P from the flower of andiroba (Carapa guianensis, Meliaceae). Tetrahedron 2012, 68, 3669. [CrossRef]

20. Kadota, S.; Marpaung, L.; Kikuchi, T.; Ekimoto, H. Constituents of the seeds of Swietenia mahagoni JACQ. I.: isolation, structures, and $1 \mathrm{H}$-and $13 \mathrm{C}$-nuclear magnetic resonance signal assignments of new tetranortriterpenoids related to swietenine and swietenolide. Chemical and Pharmaceutical Bullettin 1990, 38, 639. [CrossRef]

21. Govindachari, T. R.; Kumari, G. N. K.; Tetranortriterpenoids from Khaya senegalensis. Phytochemistry 1998, 47, 1423. [CrossRef]

22. Boeno, S. I. S.; Passos, M. de S.; Félix, M.; Calixto, S. D.; Júnior, A. R. C.; Siqueira, L. F. B.; Muzitano, M. F.; Braz-Filho, R.; Curcino Vieira, I. J.; Antimycobacterial Activity of Milemarinol, a New Squalene-Type Triterpene, and Other Isolate?. Natural Product Communications 2020, 15, 1. [CrossRef]

23. Passos, M. de S.; Júnior, A. R. C.; Boeno, S. I. S.; das Virgens, L. de L. G.; Calixto, S. D.; Ventura, T. L. B.; Lassounskaia, E.; Braz-Filho, R.; Curcino Vieira, I. J.; Terpenoids isolated from Azadirachta indica roots and biological activities. Brazilian Journal of Pharmacognosy 2019, 29, 40. [CrossRef] 